\title{
Be Right Back: Humans, Artificial Intelligence and Dasein in Black Mirror
}

Be Right Back: Humanos, Inteligencia Artificial y Dasein en Black Mirror

Be Right Back : Humains, intelligence artificielle et Dasein dans le Black Mirror

Ingrid Lacerda and Thamires Ribeiro de Mattos

\section{OpenEdition}

\section{Journals}

Electronic version

URL: http://journals.openedition.org/ctd/3353

DOI: $10.4000 /$ ctd.3353

ISSN: 2491-1437

Publisher

Chaire Unesco Pratiques émergentes en technologies et communication pour le développement

Printed version

ISBN: 2491-1437

Electronic reference

Ingrid Lacerda and Thamires Ribeiro de Mattos, "Be Right Back: Humans, Artificial Intelligence and Dasein in Black Mirror", Communication, technologies et développement [Online], 8 | 2020, Online since 30 June 2020, connection on 28 March 2021. URL: http://journals.openedition.org/ctd/3353 ; DOI: https://doi.org/10.4000/ctd.3353

This text was automatically generated on 28 March 2021.

Communication, technologies et développement 


\title{
Be Right Back : Humans, Artificial Intelligence and Dasein in Black Mirror
}

\author{
Be Right Back: Humanos, Inteligencia Artificial y Dasein en Black Mirror \\ Be Right Back : Humains, intelligence artificielle et Dasein dans le Black Mirror \\ Ingrid Lacerda and Thamires Ribeiro de Mattos
}

1 Facing every computer, tablet or smartphone, one sees its opaque reflection in a black screen. Technology, the modern technique, is present in each part of our daily life. Brazilian scholar Francisco Rüdiger $(2008,11)$ states that "modern technology is founded in a certain type of thought whose common denominator is the thought that machinery can solve any problem and satisfy all demands of the world, no matter which is the origin or nature". Rüdiger later goes beyond, affirming that the present thought has a "maximalist pretension in stating that the ultimate solution to our problems is to have machinery overcome the human being through the cyborg, and later something post-human" (Rüdiger, 2007, 176).

2 But, just for a moment, may we imagine a young engaged couple. As soon as they move to a family country house the man leaves their home in an afternoon and never comes back. He left his fiancé, Martha, helpless due to a car accident. At the funeral a friend of hers tells that she can have him back - and not by spiritual means, she highlights. The idea seems abominable at first, until she finds out she is pregnant. The loss of her beloved partner in such a delicate moment leads her to turn to the web data-based software. The processing gathers information about his involvement in social media and search mechanisms, outlining a representation of the dead fiancé. In the beginning it is a mere exchange of e-mails. However, she creates a bond to the specter and moves to the second phase - phone calls which reproduce the voice of the beloved dead. Finally, she does not resist to the final stage, and buys the identical doll and uploads all the data downloaded by the software and voilá, there is dead and buried Ash now artificially alive in perfect shape. 
3 Parting from the assumption that technology is not only understood as mere artifacts, but as a narrative about reality (Tomaz 2016a), it becomes necessary to discuss its implications in society. The confrontation of this relationship is noticeable in the British TV show Black Mirror, created by Charlie Broker, aiming to discuss the excessive interaction between humans and technology. The Guardian listed the 50 best television shows in 2016 and placed Black Mirror as $6^{\text {th }}$ in the rank. The episode described above is called Be Right Back (second season, episode one).

4 However, when we reach the point to find technique presenting itself as something body-like going beyond the virtual space, one might find it hard to distinguish what is either machine or human, and such categories appear to be insufficient in the discussion. "For one of the most important questions in our time is exactly: where does the human end, and where does the machine begin? Or, given the ubiquity of the machines, would not the order of the question be : where does the machine finish, and where does the human start?" (Tadeu 2000, 10). Thus, the question we bring forth in this study is, how can one understand the relationship between Martha and Ash's artificial intelligence doll version and its otherness? To answer such questions, we will discuss transhumanism and the question of Being through visions of Alan Turing, Nick Bostrom, Donna Haraway, counterfeiting Francisco Rüdiger, Tales Tomaz and Martin Heidegger.

\section{Modern Computing and Artificial Intelligence}

5 The modern period was marked by human being's insatiable attempts to take control of its own story. Many Technologies were used to manipulate the destiny of the beings. Activities that were prolonged and costly became more viable after the industrial revolutions. Rationality and science were considered the source to pave the way to intellectual evolution and social development, and it is in the era of the joining of forces between thought and machine that the ideas which make possible to build and develop digital computers emerged. We can highlight the projects and technological predictions of Charles Babbage, Ada Lovelace, James Thompson e Kelvin Thompson, still in the 1930s (Copeland 2008).

6 However, the concept of modern computer stems from the studies of Alan Turing (1936). He described a digital computer that consisted of unlimited memory and had a scanning system that could search for specific symbols present in memory or write / program new symbols (Copeland 2008). At the beginning of modern computing, a form of Artificial Intelligence is already implicit: the computer would be constructed harboring the possibility of changing the programming of the machine by the machine itself. Turing also made the first direct mention of artificial intelligence during a lecture in 1947 : "What we want is a machine that can learn from experience" (Turing 2004, 393).

7 Throughout the 20th century - specifically after the end of World War II - the apparent control of human destiny provided by rational principles comes under scrutiny. "This notion of overdetermination of reality seems unfeasible. It is increasingly evident, as Rüdiger (2006) says, that this was no more than an illusion of human omnipotence" (Tomaz 2014, 2). Taking that into account, "can the human mind dominate what the human mind has created ?" (Valéry apud Bauman 2001, 7). Artificial intelligences have developed, and today are accessible to the vast majority of the population that owns 
laptops, gadgets and / or smartphones. Studies already show that people not only interact with digital computers in the same way as with people but are more likely to "identify" with the interests of the computer than with that of other humans (Posard and Rinderknecht 2015).

8 To Martin Heidegger (1977), we live in the age of technological avaliability. The term implies a whole trajectory of Heideggerian thought that is constructed starting with a differentiation between Being and being. Being is a temporal event, it is the capacity to recognize, to unveil, while beings are all things, creatures, objects, everything that is known or perceptionalized. With that in mind, Heidegger (1977) calls the human Dasein. To Heidegger, although every other creature in the world is a being, humans are also described as Dasein because they are able to perceptionalize the fact that other beings exist. Marco Casanova (2009) affirms that this notion comes from the idea of facticity in Heidegger, term that designates "Exactly an articulation between knowledge, truth and singular life", "an existential opening", that is, the combination of what is found in being in the world and the relation to it, a fact in which lies a primordial question of philosophy. (CASANOVA, 2009, p. 22-24).

9 As Tomaz (2016b) puts it, the Dasein is a "permanent opening". If technology is a "way to uncover" or to "bring forth", it is a way of Being - the way the Being reveals itself in the age of technology (Heidegger 1977; Tomaz 2014). The uncovering of the Being in technology is in likeness of availability ; that is, entities are available for manipulation, so that they are able to perform certain purposes; therefore, technology is a way of Being and acting in which things appear as objects and these can be used to perform other activities (Tomaz 2016b).

10 This does not mean that digital computers endowed with artificial intelligence have reached the human level of existence, but that humanity has gone the opposite way, objectifying beings and their relations. There are no more subjects; only objects. This implies that

The old days of separation between natural and artificial, in which the artificial was normally seen as a mere human instrument for the attainment of its goals, were left behind. The artifice we create recreates us and becomes the very raw material from which we derive the repertoire to establish our relations with things and others (Tomaz 2017, 19).

11 The human is therefore placed as availability, as object, and not as subject, modifying its relations with the real world. The same thing happens in the so-called virtual reality, which can be defined as "a space that appears from computing technology", where "a window for a new world opens before the human being, mediated by interfaces" (Paulienne 2016, 18). There is no longer any difference in dealing with the two realities, because the same logic is established in both : the signs - corporeal or not - disposed there are available for use. This way of thinking will lead us in the next topic to the discussion of the human seen as a product or as a commodity. Nick Bostrom $(2005 a ; 2005 b)$ proposes that the process of human enhancement makes perfect sense since we are made of a kind of matter that obeys the laws of nature operating outside the individual. So, in principle, it would be possible to learn how to manipulate human nature just as manipulating external objects. This view clearly reveals technical thinking as a guiding force on the quest to view the human being as availability through his corporeal matter. 
12 Therefore, if before we would confront virtual reality in the sense of an insuperable screen, or as an environment that withdraws us from the "organic sense of touch" and obligates us to face a "collapse of the aesthetic distance involved in looking", we now note that the virtual environment actually brings a fascination that fills our emptiness - "proxemics of images; promiscuity of images; tactile pornography of images. Yet the image is always light years away" (Baudrillard 1993, 55). In other words, there is no longer fear or fright of losing our humanity when facing virtuality, the fascinating imagery temptation made doubtful the fine line between real and virtual, between human and machine.

\section{The commoditization of humans}

13 Some concerns of the scientific community and of science fiction about the super artificial intelligences, like the Ashbot from Be Right Back, come from ideas favoring the constant "improvement" of what it means to be human: we must be prepared to be refined, evolved, modified - even if it costs us the loss of what we consider presently as human (Baudrillard 2000). A term that can be adequate for this status of the human being, as it was mentioned before, is commodity - the term refers to any kind of stock that can be purchased or sold (Oxford Living Dictionaries 2017). The ethimological source of commodity is in the Word commodus : "suitable, fit, convenient, commodious, easy, appropriate, favorable, friendly". (Lewis 1891, 146). The irony is explicit: the human being has defined himself more and more by a term that implies its padronization.

14 The difference between the concepts of human being as a property and human being as commodity must be highlighted. While the first concerns the sense of property that a person has upon itself, and the territorial perception of one's body and mind, the second, however, is about goods alienable to oneself. According to David Resnik (1998), the human commodification has two basic formats: parcial and generalized. Cells, tissues, organs and data of the body and/or human behavior that are bought and sold are part of partial commodification. Also, under such classification we find actions like blood donation, organ donation of a living human to another, esthetical modification and other procedures. A simple and viable example here is that when a person cuts of some centimeters of its own hair, for he or she does not cease to exist in a holistic matter due to such event. Thus, these practices do not affect directly the oneness of a human being (Resnik 1998).

15 However, personhood, although different from corporeality, is within it; the two coexist. It is important to notice that this analysis does not adopt a platonic vision of the human, believing in the separation between body and soul/mind. But we can't help to notice that some bodily elements do not directly affect personhood and vice versa. Even though we think of people as bodies, we do not see specific body parts as people. Another possible example is that selling an alive human body corresponds to selling someone's personhood, just as having absolute control over someone's body corresponds to slavery. Only those that maintain a rigid platonic dualism between body and mind are not able to admit that there is an intimate and raw relation between the both of them (Resnik 1998).

16 The partial commodification of the human is generally allowed, while the generalized one is not. The reason for this is the intrinsic connection between the personality and 
the corporeality of the human - something not alienable. This perspective adopted by Resnik is a combination of principles posed by Jean Baudrillard and Donna Haraway. In describing humanity, Baudrillard argues that the human species is "unable to brave its own [...] alterity" (Baudrillard 2000, 15), and for this reason there is a technical impulse for the standardization of the human. In this search, however, we are all endangered of never really discovering what is in fact human - after all, reality itself is an illusion (Baudrillard 1983). Haraway also focuses on the issue of otherness and rejects genetic determinism by stating that "Bodies [...] are not born ; they are made" (Haraway 1991, 208). It is important to note that, in Haraway's view, the "body" encompasses both the physical and the mental dimensions.

17 When these concepts are applied to the episode Be Right Back, we come to terms that Ash's body was commoditized to its extreme. After all, all of him that was available in both physical and virtual dimension was replicated, giving birth to a type of Ash that does not get tired, does not feel pain, does not age. Though it seems an improved version of his original human, the Ashbot does not include the human distinctions, like imperfection and inconstancy. A great deal of Martha's complains related to the robot are precisely critics referent to the absence of these attributes. When the Ashbot tries to transpire imperfections and inconsistencies his behavior is seen as a performance. Even when the super artificial intelligence affirms to "feel" scared his screams, for instance, seem programmed. That is why Ash (the human) does not become Ashbot (the machine), though he was commoditized completely. He is a mere simulation of who one day was human (Baudrillard 2000).

\section{New Creatures : Cyborgs, Transhumans, and Post- Humans}

18 As previously mentioned, Rüdiger $(2008,11)$ affirms that "modern technology is founded in a certain type of thought whose common denominator is the thought that machinery can solve any problem and satisfy all demands of the world, no matter which is the origin or nature" and that is why "we conceive the very lowly reasonable project of solving technically all of our problems and limitations, to the point of cancelling ourselves and finding sublimation in some kind of machine-like organism" (Rüdiger 2008, 14). Thus, technology as a way of being, like stated by Heidegger (2007), is not only the way an individual understands himself as a being, but also the means by which he attempts to comprehend and "fix" the world.

19 It is important to trace the difference between the concepts that refer to such amalgamation between human and machine. To begin with, we must establish the difference between transhumanism and post-humanism. The first refers to human enhancement or upgrading, to the process in which human is coated with technology. Nick Bostrom (2005a, 14) brings the following examples of such idea: "prostheses, plastic surgery, intensive use of telecommunications, a cosmopolitan outlook and a globetrotting lifestyle, androgyny, mediated reproduction (such as in vitro fertilization), absence of religious belief, and a rejection of traditional family values". Posthumanism, on the other hand, is the aimed state in which one would exceed oneself or transcend humanity, reaching a state that should follow humanity in historic evolution. 
20 Another term to be considered is "cyborg". Donna Haraway defines it as "a cybernetic organism, a hybrid of machine and organism, a creature of social reality and also of fiction" (Haraway 2009, 36). Similarly, Tomaz Tadeu $(2009,12)$ adds to the definition the idea of a creature that emerges from the combination of two processes (that have been previously discussed by other authors) : the "mechanization and electrification of the human" and the "humanization and subjectivity of the machine". However, for Tomaz Tadeu, the discomfort of the discussion is founded in the necessity that the cyborg provokes of decentralizing man from history and dissociating some of his attributes as exclusively his.

If there is, however, a technohuman creature that simulates the human, who in everything seems human, who acts as a human, who behaves like a human, but whose actions and behaviors can not be retroacted to any interiority, to any rationality, to no essentiality, in short, to none of the qualities we use to characterize the human, because made of streams and circuits, wires and silicon, and not of the soft and soft fabric of which we are still made, then it is the very singularity and exclusiveness of the human that dissolves (Tadeu 2009, 13).

21 Here we find one of the premises of which post-humanism parts - the emphasis in the fact that we still are humans, made of skin tissue as we know it, but that the possibility of becoming more resistant and even eternal through technology is actually a natural response to science evolution, as if likewise the history of humanity begin with unicellular evolving processes it would now lead us to convert into humanoid machines, and from further on. Such thought is noticed in the work of Nick Bostrom and Donna Haraway. She calls herself "a cyborg - a kind of body that represents technology's quintessence” (Kunzru 2009, 20).

22 Though such affirmation might be frightening, it does not imply necessarily to be living under a modified embodiment. According to the interview held by Kunzru (2009, 22-23), Haraway assures that "modern life realities implicate in such an intimate relationship between people and technology that it is not possible to determine where we end and where machines start". Going beyond the possibility of exemplifying our closeness with technological objects, specially electronics, it is undeniable the interference of science and technology in human daily basis aiming to enhance the living, not only in our activities but also our own body - prosthetics, plastic surgeries, or even as Haraway mentions through Kunzru, bodybuilding, in such way that the body is seen as a "high performance machine" (Kunzru 2009, 32). It is important to note that, for her, technology is not neutral, instead we establish two-way relations with that which we do inside a world of connections, so that "it is important to know who is made and unmade". For Haraway, "communication technologies and biotechnologies are crucial tools in the process of remodeling our bodies" (Haraway 2009, 64).

23 It is interesting to note that in the core of Donna Haraway's thought lays a fundamental matter that appears to be similar to that of Heidegger - though it took a totally opposite direction : the Idea that the essence of technology is not neutral and acts in the history of humanity in such way that it modifies the relations and the understanding of the individuals, so that these processes Begin to happen through technology. However, the difference is that while the German philosopher sees in such recognition the possibility of freedom from the technical way of being as an ultimate truth and the openness to other ways of being, the American biologist considers it the destiny of humanity to accept us as cyborgs and embrace technology. 


\section{Is otherness an attribute of humans and machines?}

24 Returning to our characters of the Black Mirror episode, we notice that a new question rises about them. If Ash and Ashbot are different beings and the oneness of Ash cannot be transferred to the replicant that intends to simulate him, could we consider that the Being showed itself differently in the two of them towards Martha? Could her negative reaction towards the machine version of her dead fiancé be an evidence of such difference? In this logic, the otherness of Ash would have perished along with his death ; nevertheless, does Ashbot also have otherness - and if he does is it authentic or forged, once he was programmed to relate to an Other and reproduce mechanically the reactions of this Other? Due to such uncertainties, would this product offered by the clandestine company of this posthumous service be a frail proposal in its own efficiency?

Tomaz Tadeu $(2009,9)$ discusses a change in these questions that do not have an easy and simple answer. To him, we should not worry so much about who is the subject, but instead ask ourselves if we still want to be subjects - or even wonder, who needs or is nostalgic about the subject? At last, one might ask, what comes after the subject? Brazilian scholar Tales Tomaz defines otherness as "Other's characteristic, whom with we establish a relationship" and "a question about the possibility of a relationship with another being" (Tomaz 2016b, 1). While Tomaz asks what makes an Other different from us and not an extension of ourselves, in transhumanism and posthumanism the question is where human ends and machine begins.

Given that otherness means to get in contact with an Other, or have access to an Other, it is necessary to perceive the Other. Hence, we will go to Heidegger (1988) in The Basic Problems of Phenomenology to understand the concept of perceptionality. As Tomaz well summarizes the heideggerian thought, "perception is, therefore, an aiming towards the percepted". This means that the percepted, the one to whom one directs itself, should perceive himself as a target of intentionality. This is a phenomenological structure, formed of intentio, the act of directing oneself towards an Other, and of intentum, that who is percepted.

This short explanation referred to human beings; still, there is the doubt if a posthuman creature as Ashbot has the ability to note himself as perceived in his perceptionality, or even, if he is able to own intentionality when interpellating another being. However, turning back to the technical way of being in which all beings are seen as an availability, it is relevant here to consider the interactive communicational media, where the beings expose themselves as spectrums and build their personas, and it is towards these personas that we interpellate through text, audio and video messages. Yet, "even the interpellation of Other in the new media only works because we have already minimized what Other is"; and "in that sense, it doesn't really matter if Another physical being is behind the signs" (Tomaz 2016b, 12). This same idea exposed by Heidegger concerning the reduction resulting from viewing the Other as available is also considered by Jean Baudrillard $(1993,1999,2000)$ in a quite similar approach, with implications close to forgetfulness and death of the human.

For the transhumanists and post-humanists, this discussion loses strength due to some premises held by these defenders that appear to diverge in a totally opposite lane from the phenomenological views in its core. Nich Bostrom in his A history of transhumanistic thought, brings a dialogue between different authors of both sides - however, as his 
previous quotes revealed, his thought is favorable to the advances of human upgrading and the creation of artificial intelligences. It is relevant to notice in his work the core of the difference in the path these thinkers trace on viewing the human being and why does it end in such opposing sides.

Bostrom (2005a) mentions the "yuck factor", term that summarizes the feeling of repulse and demonizing of the trans and post-human ideas. He quotes two opposing thinkers : 1) the British biochemist J. B. S. Haldane, who affirms that from the myths through history, scientific novelties always brought estrangement and dreadfulness for people in general, but the benefits of genetic manipulation, for example, would be inevitable ; 2) the president of the counsel of bioethics in G. Bush era, Leonard Kass, to whom the aversion feeling caused by such ideas are signs of "wisdom" that comes from the "gut" of the individuals as a response to the feeling of violation of factors of high attachment. For the bioethics that corroborate this view, exposed in the text through the view of prominent bioconservative Francis Fukuyama, the human beings are gifted with something undefined called Factor X, "which grounds their equal dignity and rights. The use of enhancing technologies, he fears, could destroy Factor X" (Bostrom 2005a, 24).

This basic divergence refers to a supposed undefined human "essence" that would represent a special value or dignity is only an example of how the paths in relation to trans and post-humanism are traced. Bostrom also wrote in his text "In Defence of Posthuman Dignity", where he discusses the acceptance of an artificial intelligence (AI) in society and aims to discuss about the biggest fears of people regarding the presence of AIs among us, such as the subjugation and even extinction of human beings. As one may notice, this discussion comes to an end where it appears to be remote compared to what was previously exposed in this study, regarding the technical way of being that converts everything, even the human being, in availability. Although, once the technologic view crosses all paradigms and arguments in favor of scientific development, a reflection about such matters becomes necessary.

\section{Final Thoughts}

31 The discussion about the technical availability of the human being and the otherness of artificial intelligences can be laid in a statement of Nietzsche : "Man is that animal which is yet to be defined" (apud Heidegger 2013, 9). This phrase implies that the human being will always be a disturbing factor in the technical cycle that he imposed himself. Thus, we see that humans cannot be controlled - and consequently will never be totally emulated by an artificial intelligence. In the case of Be Right Back the simulation of Ash, the Ashbot, does not convince Martha of its humanity. He lacks its original's flaws. That is exactly what Martha misses in it : the unpredictability, the mess and imperfectness that she found in Ash. The irony of the Ashbot is the client's insatisfaction.

32 The viewer can also notice that Ash, as a human, was commoditized while He was still alive - after all, the material that originated the Ashbot were his own posts in social media and all of his online activities. Martha, who initially was against excessive virtual exposition - and thus to the partial commoditization of Ash - turns him into a total commodity when decides to interact with the Ashbot in the three stages (text messages, audio and synthetic body). Martha finds comfort, though briefly, in the 
interaction with the non-human; with Ash's spectrum, therefore revealing that her life too is led by the emptiness of simulation, by the ghost of de-humanization (Baudrillard 1984).

33 The otherness between human and machine in Be Right Back does not depend on the machine in question (Ashbot), but on the perception that the human being creates of it. Initially Martha believes that the artificial intelligence is equal to her dead fiancé. As time goes by, she becomes skeptical and the otherness is extinct. At first sight, the human being (Martha) owns the simulating machine; but in reality she places herself in the role of a machine many times because she is not able to fulfill her own humanity. After all, what is humanity besides its imperfections and unpredictable characteristics? To Baudrillard, everything and everyone in the universe has in its essence something that cannot be measured, counted, seen - "a fundamentally inaccessible secret" (Baudrillard 2000, 80). The idea of a "secret" reminds the "Being" in Heidegger's writings that cannot be fixed nor controlled (Heidegger 1977). Be Right Back captures such concepts and incorporates them in a situation of dystopic fiction that exposes the emptiness caused by the simulation and how we "run in circles" when trying to uncover and fix the human in a machine.

\section{BIBLIOGRAPHY}

Baudrillard, Jean. 1983. Simulations. Los Angeles : Semiotext[e].

Baudrillard, Jean. 1993. The Transparency of Evil : Essays on Extreme Phenomena.London : Verso.

Baudrillard, Jean. 1999. A Troca Impossível. Rio de Janeiro : Nova Fronteira.

Baudrillard, Jean. 2000. The Vital Illusion. New York : Columbia University Press.

Bostrom, Nick. 2005. “A History of Transhumanist Thought.” Journal of Evolution and Technology 14 (1) : 1-25.

Bostrom, Nick. 2005. “In Defence of Posthuman Dignity." Bioethics 19 (3) : 202-14.

Casanova, Marco Antonio. 2009. Compreender Heidegger. Petrópolis : Vozes.

Copeland, Brian Jack. 2008. "The Modern History of Computing." Essay. In The Stanford Encyclopedia of Philosophy. Stanford : Stanford University. https://plato.stanford.edu/archives/ fall2008/entries/computing-history/.

Haraway, Donna. 1991. Simians, Cyborgs, and Women : the Reinvention of Nature. New York: Routledge.

Haraway, Donna, and Tomaz Tadeu. 2009. "Manifesto Ciborgue : Ciência, Tecnologia e Feminismo-Socialismo No Final Do Século XX." Essay. In Antropologia Do Ciborgue : as Vertigens Do Pós-Humano, 33-118. Belo Horizonte : Autêntica.

Heidegger, Martin, and William Lowitt. 1977. “The Question Concerning Technology.” Essay. In The Question Concerning Technology and Other Essays, 3-35. New York : Harper and Row. 
Heidegger, Martin. 1988. The Basic Problems of Phenomenology. Bloomington : Indiana University Press.

Heidegger, Martin. 2013. "The Provenance of Art and the Destination of Thought." Journal of the British Society for Phenomenology 44 (2) : 119-28.

Kunzru, Hari, and Tomaz Tadeu. 2009. “'Você é Um Ciborgue’ : Um Encontro Com Donna Haraway.” Essay. In Antropologia Do Ciborgue : as Vertigens Do Pós-Humano, 17-32. Belo Horizonte : Autêntica.

Lewis, Clive Thomas. 1891. An Elementary Latin Dictionary. New York : Harper and Brothers.

Paulienne, Kendra, and Tales Tomaz. 2016. “Uma História De Amor Com o Virtual.” Essay. In Sociabilidade e Comunicação : Dilemas Na Cibercultura, 17-50. Engenheiro Coelho : Unaspress.

Resnik, David. 1998. “The Commodification of Human Reproductive Materials.” Journal of Medical Ethics 24 : 388-93.

Rüdiger, Francisco. 2006. Martin Heidegger e a Questão Da Técnica : Prospectos Acerca Do Futuro Do Homem. Porto Alegre : Sulina.

Rüdiger, Francisco. 2007. Introdução Às Teorias Da Cibercultura. Porto Alegre : Sulina.

Rüdiger, Francisco. 2008. Cibercultura e Pós-Humanismo : Exercícios De Arqueologia e Criticismo. Porto Alegre : EDIPUCRS.

Tadeu, Tomaz, and Tomaz Tadeu. 2009. "Nós, Ciborgues : O Corpo Elétrico e a Dissolução Do Humano." Essay. In Antropologia Do Ciborgue : as Vertigens Do Pós-Humano, 7-17. Belo Horizonte : Autêntica.

Tomaz, Tales. 2017. "Máquina Como Outro Comunicativo : Crítica Da Concepção Cibernética à Luz Da Fenomenologia De Heidegger.” PhD diss., University of São Paulo, 2017.

Tomaz, Tales, Arlete Petry, Eneus Trindade, Luís Carlos Petry, and Nicolás Llano Linares. 2014. "Pensamento Técnico : Paradoxo Da Ilusão De Onipotência Humana." Essay. In Comunicação e Antropologia Visual, 336-49. São Paulo : INMOD / PPGCOM-ECA-USP.

Tomaz, Tales. 2016. "XXXIX Intercom - Congresso Brasileiro De Ciências Da Comunicação." In XXXIX Congresso Brasileiro De Ciências Da Comunicação. São Paulo : Intercom.

Tomaz, Tales, and Tales Tomaz. 2016. "Prefácio." Essay. In Sociabilidade e Comunicação : Dilemas Na Cibercultura, 7-15. Engenheiro Coelho : Unaspress.

Turing, Alan. 1936. "On Computable Numbers, with an Application to the Entscheidungs Problem." Proceedings of the London Mathematical Society, 2, , no. 42 : 230-65.

Turing, Alan. 1950. “Computing Machinery and Intelligence.” Mind 59 (236) : 433-60.

Turing, Alan, and Brian Jack Copeland. 2004. "Lecture on the Automatic Computing Engine." Essay. In The Essential Turing: Seminal Writings in Computing, Logic, Philosophy, Artificial Intelligence, and Artificial Life, plus The Secrets of Enigma, 362-94. Oxford : Oxford University Press.

\section{ABSTRACTS}

The present article aims to analyze the relationship between the human being and artificial intelligence through the episode Be Right Back of the dystopic television show Black Mirror, currently exhibited by Netflix. For this discussion we will bring forth the contrasts between the thoughts of Martin Heidegger about Dasein and human nature, and studies derived from the 
perspectives of Alan Turing about artificial intelligence and humanity, besides the visions of post-humanism and transhumanism, as well as their implications in the relationships between human beings. It is also an objective to discuss the presence of otherness in an artificial intelligence. Hence, it is asked in this article how it is possible to understand the otherness found between Martha, the protagonist of the episode, and an Artificial Intelligence which is created with the function of substituting her dead fiancé, Ash. For this study we will part from assumptions on the question of technique found in Heidegger's conception of Dasein and Being, opposed to the technique worldview as a way of being that rules post-modern thought.

El presente artículo pretende analizar la relación entre el ser humano y la inteligencia artificial a través del episodio Be Right Back del programa de televisión distópico Black Mirror, actualmente exhibido por Netflix. Para esta discusión, presentaremos los contrastes entre los pensamientos de Martin Heidegger sobre el Dasein y la naturaleza humana, y los estudios derivados de las perspectivas de Alan Turing sobre la inteligencia artificial y la humanidad, además de las visiones del post-humanismo y el transhumanismo, así como su Implicaciones en las relaciones entre los seres humanos. También es un objetivo discutir la presencia de la otredad en una inteligencia artificial. Por lo tanto, en este artículo se pregunta cómo es posible comprender la alteridad que se encuentra entre Martha, la protagonista del episodio, y una Inteligencia Artificial que se crea con la función de sustituir a su novio muerto, Ash. Para este estudio, partiremos de los supuestos sobre la cuestión de la técnica que se encuentra en la concepción de Dasein y el Ser de Heidegger, en oposición a la visión del mundo de la técnica como una forma de ser que gobierna el pensamiento posmoderno.

Cet article a pour objectif d'analyser la relation entre l'être humain et l'intelligence artificielle à travers l'épisode Be Right Back de l'émission télévisée dystopique Black Mirror, actuellement présentée par Netflix. Dans cet article, nous présenterons les contrastes entre les réflexions de Martin Heidegger sur le Dasein et la nature humaine, et les études dérivées des perspectives d'Alan Turing sur l'intelligence artificielle et l'humanité. Nous aborderons également les visions du post-humanisme et du transhumanisme ainsi que ses implications dans les relations entre les êtres humains. L'un de nos objectifs sera également de débattre de la présence de l'altérité dans une intelligence artificielle. Par conséquent, cet article interroge la possibilité de comprendre l'altérité qui existe entre Martha, la protagoniste de l'épisode, et une intelligence artificielle créée pour remplacer son petit ami mort, Ash. Pour cette étude, nous allons partir des hypothèses sur la question de la technique qui se trouve dans la conception de l'Être de Dasein et Heidegger, en opposition à la vision du monde de la technologie en tant que manière d'être qui gouverne la pensée postmoderne.

\section{INDEX}

Mots-clés: Intelligence artificielle ; Black Mirror ; Martin Heidegger ; Post-humanisme ; Transhumanisme

Keywords: Artificial Intelligence ; Black Mirror ; Martin Heidegger ; Post-humanism ; Transhumanism

Palabras claves: Inteligencia artificial ; Black Mirror ; Martin Heidegger ; Post-humanismo ; Transhumanismo 
AUTHORS

INGRID LACERDA

Federal University of Bahia, Brazil

THAMIRES RIBEIRO DE MATTOS

University of Campinas, Brazil 